\title{
Masonry's Resistance to Driving Rain: Mortar Water Content and Impregnation
}

\author{
Fredrik Slapø ${ }^{1, *}$, Tore Kvande ${ }^{1}$, Noralf Bakken ${ }^{2}$, Marit Haugen ${ }^{2}$ and Jardar Lohne ${ }^{1}$ \\ 1 Department of Civil and Environmental Engineering, Norwegian University of Science and \\ Technology (NTNU), NO-7491 Trondheim, Norway; tore.kvande@ntnu.no (T.K.); jardar.lohne@ntnu.no (J.L.) \\ 2 SINTEF Building and Infrastructure at Department Architecture, Materials and Structures, \\ NO-7465‘Trondheim, Norway; noralf.bakken@sintef.no (N.B.); marit.haugen@sintef.no (M.H.) \\ * Correspondence: slapoe@gmail.com; Tel.: +47-926-40-717
}

Received: 16 June 2017; Accepted: 3 August 2017; Published: 9 August 2017

\begin{abstract}
Alongside well-researched themes such as water and moisture, the service life and function of masonry veneers are often compromised by precipitation combined with poor design considerations, execution, and selection of materials. Little research has been carried out on the subject of the impact of mortar consistency on masonry's resistance to driving rain. Water-repellent (WR) impregnation is typically considered a quick fix when problems occur. Wall-panels of $1 \mathrm{~m}^{2}$ built with different flow table values for the mortar have been tested in a driving rain chamber, where both time-lapse videos and the measuring of penetrated water are used to evaluate performance. Subsequently, the panels were impregnated with the most common types of WR products and re-tested. The analysis shows that changing the mortar mix from dry to wet can decrease the penetration of driving rain by a factor of ten. The test results presented in this article show that mortar with low water content gives a porous interfacial transition zone (ITZ), thereby increasing the rate of water penetration. The tested WRs are found to be ineffective in increasing masonry's resistance to high pressure driving rain. The results, combined with what is already known about WR treatments on masonry, call for careful consideration before applying such treatment. This proves especially true in countries with much driving rain followed by frequent freeze-thaw cycles.
\end{abstract}

Keywords: driving rain; mortar flow; impregnation; clay brick masonry; workmanship techniques

\section{Introduction}

Climate changes are assumed to result in a warmer and wetter climate in Norway [1,2], leading to an increased risk of defects and the early decay of buildings. The construction industry has a considerable challenge in adapting buildings to the new and harsher climate. Masonry veneers are regarded to be a long life, low maintenance façade material and thereby well adapted to a harsh climate. However, warmer and moister conditions will lead to new challenges for the performance of masonry within the Norwegian context [3], particularly related to increased amounts of rain. This proves especially true in combination with the increased challenge posed by more frequent freeze-thaw conditions in new regions of the country, in particular the densely populated areas around the capital Oslo.

The increased risk of defects and early decay in buildings inflicted by the new physical conditions caused by climate change are clearly not limited to Norway. This country, however, experiences some challenges that are exemplary, in that they push the consequences of the changes to a conceptual and physical endpoint. In particular, the very common (and frequent) freeze-thaw conditions generally experienced in the coastal regions of Norway will spread, exposing huge parts of the mass of buildings and infrastructure to new and potentially very harmful conditions. Norway, with its geographical and 
physical conditions, is in many respects unique, but lessons from this country will serve less exposed countries and regions with data on how to tackle similar problems, if to a lesser degree.

Even though masonry ought to endure driving rain well over time, the extent of costly faults and defects is discouraging. Problems are in general caused by water, or rather by the combination of water, lack of knowledge, and poor design or execution [4]. Of particular consequence to the quality of masonry is the influence of frost. Limiting the water content of masonry veneers limits the risks of damages influenced by frost [5]. Masonry in Norway is especially exposed to this challenge since large parts of the country experience very frequent freeze-thaw cycles [5]. Though the actual influence of frost is not assessed in this article, frost challenges render the analysis carried out in this article, on the permeability of masonry under driving rain conditions, crucial to the Norwegian industry.

One common measure to improve the resilience of masonry to driving rain is impregnation [6]. Two types of studies have been found; studies using brick or parts of bricks and studies with masonry. When only looking at the bricks, studies generally show a good effect of impregnation with various water-repellents $[7,8]$, significantly slowing down water absorption into the brick, thus rendering them more resistant to frost degradation. Studies on masonry show a potential to decrease the durability of the treated masonry. Šadauskienè et al. [9] found that hydrophobic treatment was unable to significantly reduce the water permeability of masonry, allowing water to penetrate through the brick mortar (ITZ). This poses a problem since the treatment has reduced the vapour conductivity of the masonry. This leads to the treated masonry failing prior to the untreated masonry during a simulated climate load of moistening-freezing-heating cycles.

Specifications on the workmanship are equally imposed to improve the performance of masonry. Design guidelines in Norway demand full bed and head joints in masonry, identified as the prime factor for assuring the resistance of masonry to rain [10]. The main reason for this demand is the perceived need to obtain impermeable masonry to the greatest extent possible. 'Full' is defined [11] as $85 \%$ for head joints and $90 \%$ for bed joints, with no holes in the outer half of the joints. The standard NS 3420-N [10] does not, however, specify the choice of bricks or the properties of the fresh masonry mortar to be used.

Based on the experience of the main author in this article, being an experienced practitioner in the field, the water content in fresh masonry mortar actually found on building sites varies strongly. The hypothesis of this article is that mortar water content is crucial to achieve high quality masonry. This, however, seems to be a rather neglected factor in the research literature aiming to achieve high quality masonry. To address this general challenge, we address the following research questions:

- What is the influence of fresh mortar water content on the resistance to driving rain of un-impregnated masonry?

- What is the influence of impregnating masonry against driving rain?

To address the first of these questions, four panels were tested. The panels varied with respect to the water content of the mortar used (dry, medium, wet) and the workmanship techniques (panels built with the wet mortar were built with two separate techniques). To address the second, the same panels underwent impregnation prior to retesting in order to assess the potential for improving the driving rain resistance of masonry using impregnation.

\section{Theoretical Framework}

\subsection{Principal Function of Masonry Veneer: Common Practice in Norway}

Bricks are commonly used as non-structural veneers, where their function is to protect buildings from wind, rain, and sun. Loading is mostly limited to self-weight, wind, and thermal expansion loads. Brick veneers are normally half a brick thick and water permeable. Water that penetrates the veneer is drained down the backside of the bricks and out through weep holes. The weep holes also provide some ventilation of the air gap and help to dry the wall. Stiff mineral wool insulation plates 
are designed for masonry veneers. The arrangement of bricks stopping most of the rain combined with a vented and drained cavity before the wind barrier complies with the dual layer climate screen principle; see Figure 1 [12].

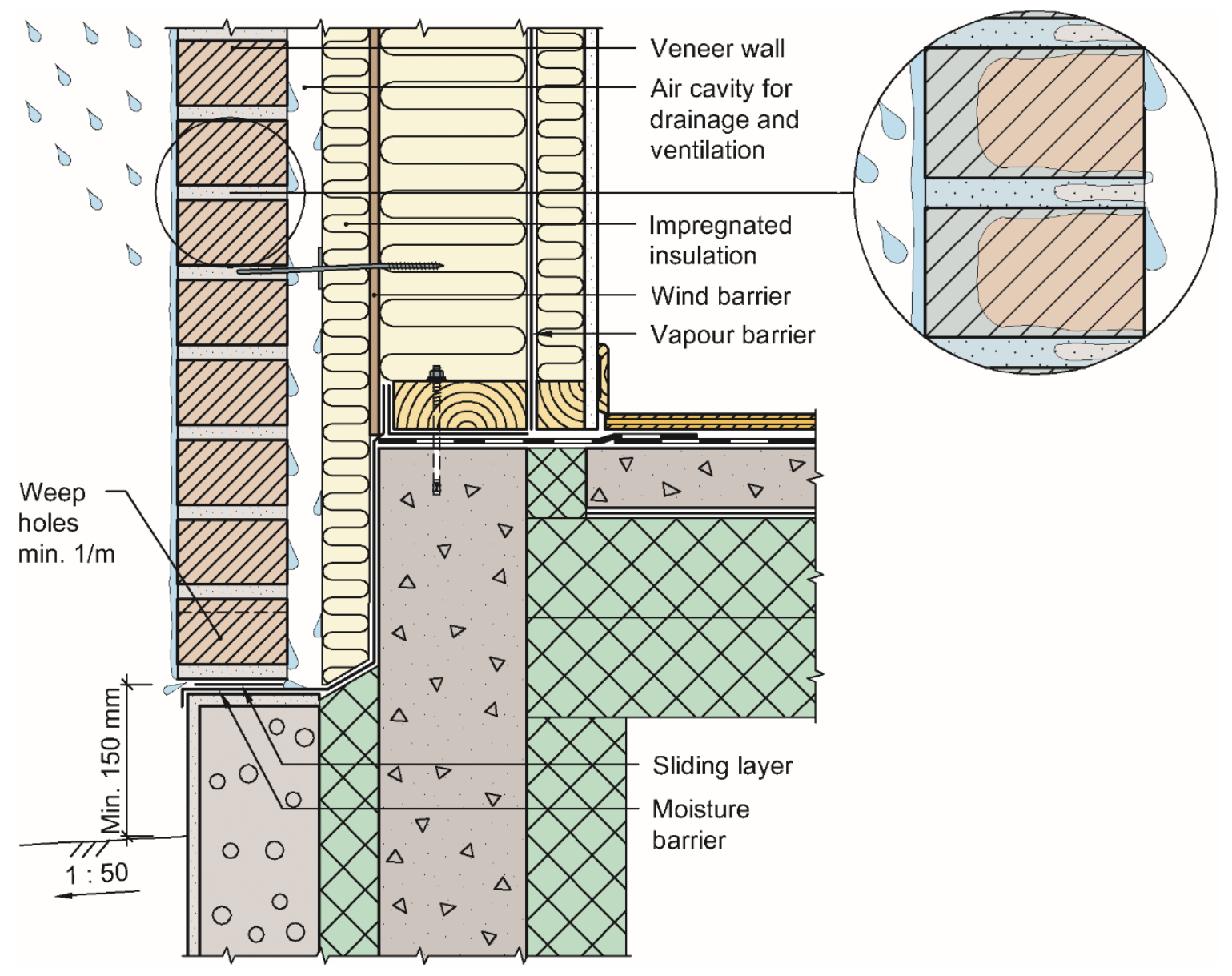

Figure 1. Masonry veneer: principal function.

The specificities of the traditional Norwegian manner of constructing masonry buildings helps, effectively, to surpass the problem of flooding caused by an excess of rain. In Figure 1, a principle outline of a traditional masonry structure is illustrated. In this, the masonry structure is lifted from the ground, whilst sub-terrain structures are typically constructed in concrete, separated by a moisture barrier.

There are no explicit requirements to the degree of water-tightness of masonry veneers in Norway. Full bed and head joints are required [12], and the recommended workmanship technique to ensure full head joints is to butter the head of the brick prior to laying [13].

\subsection{Driving Rain in Norway}

Driving rain is rain driven by winds to fall at an angle, allowing it to hit vertical surfaces. Factors like local conditions affecting the wind, mountains, and fjords or buildings can cause large precipitation variations [14]. The driving rain map of Norway (Figure 2) is based on long term averaged values and is representative of long term events such as the accumulation of moisture in porous materials [3]. The map presents the amounts of annual driving rain (illustrated with a colour scale) from the main wind direction (indicated with arrows) that gives the highest amounts of driving rain at each observing station. 


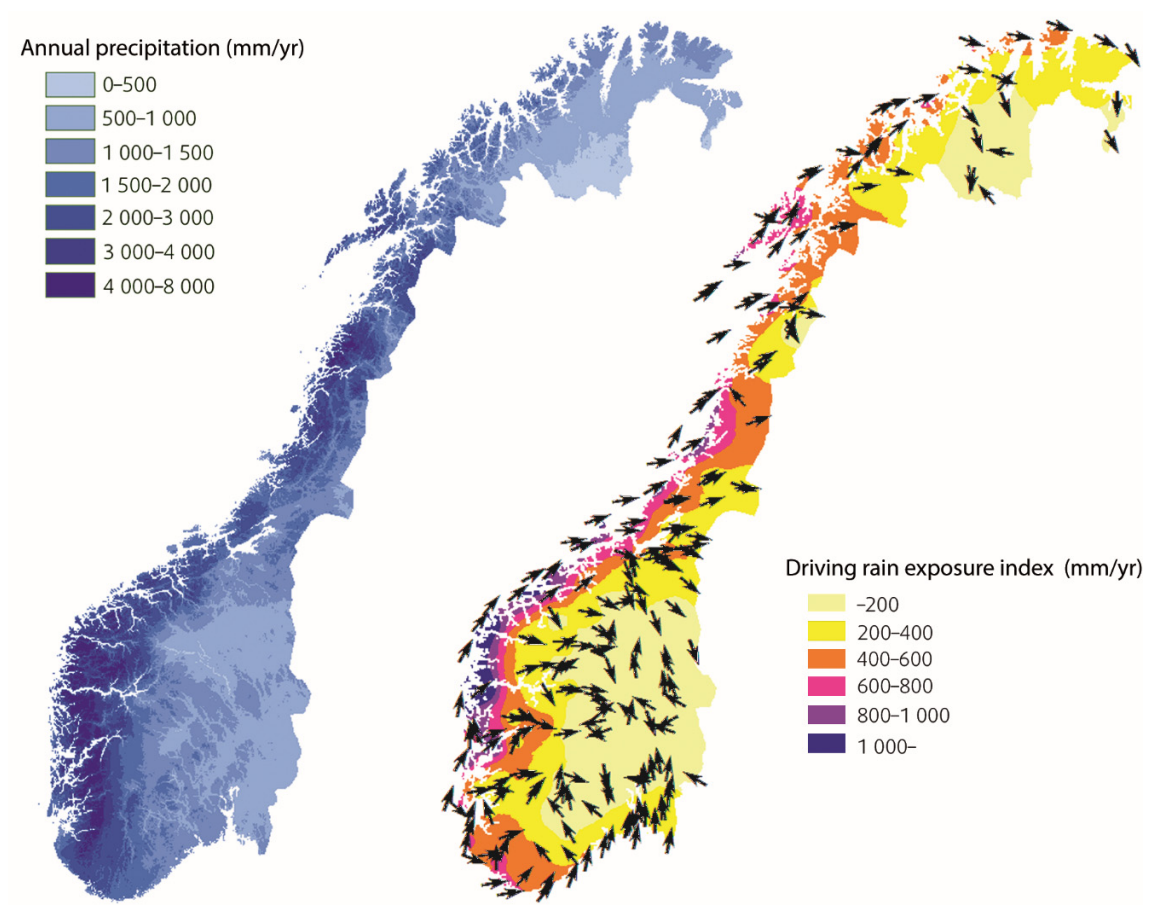

Figure 2. Annual precipitation and driving rain map of Norway for the normal period from 1961 to 1990. Raw data provided in [15].

\subsection{Defects in Masonry}

Masonry veneers are designed to withstand harsh climate conditions even if they are not watertight, provided they are designed and built correctly. Even so, there are costly and unnecessary defects to both new and old masonry veneers in Norway today. Most of these defects (up to 80\%) [16] are related to moisture. Defects vary and are often caused by a combination of factors. Kvande and Lisø [16] have categorized the defects of masonry in Norway from 1983 to 2002. In this categorization, they found 'deficient rain barrier' to be the main cause in $14 \%$ of the cases and 'lack of compatibility (adhesion)' in $6 \%$. These two categories amount to a total of $20 \%$ and are regarded by the authors to be directly related to the scope of this article. Other common causes of defects regarded to be indirectly related are 'deficient flashing', 'insufficient durability of masonry units', 'deficient drainage of the wall', 'reinforcement corrosion', 'aesthetic problems', and 'salt eruption'. These indirect causes amount to a total of $39 \%$ of the defects.

\subsection{Clay Brick Masonry Resistance to Driving Rain}

There are three ways for water to penetrate a sound brick wall: through the bricks, through the mortar, or through the brick mortar interfacial transition zone (ITZ). According to Groot and Gunneweg [17], the main ways are through the bricks for high suction (high initial rate of absorption (IRA)) bricks and the ITZ for low to moderate suction bricks. Water-penetration and bond are closely related. Goodwin and West [18] report that researchers, when investigating the bond, often test water-penetration and use the indirect values as an indication of bond strength. If the bond has a strong correlation to the water-penetration, then the water-penetration also has a strong correlation to the bond. Groot and Gunneweg [17] also state that hydraulic mortar has significantly improved the barrier effect, compared to mortars lacking hydraulic components.

\subsection{The Influence of Mortar Water Content on Driving Rain Resistance}

Bowler et al. [19] found that mortar cohesivity strongly correlated with rain penetration. The more cohesive the mortar, the better the resistance to the penetration of water. Mortar cohesivity is defined 
as the mortar's ability to hold together and to stick to various surfaces. Bowler judged the cohesivity of the mortar by the use of a flow table, wherein a smaller spread (for a constant consistency) indicated more cohesivity. The consistency was measured by a plunger test.

Internationally, no articles addressing the specific question of the influence of water content in mortar on the water permeability of masonry veneers has been identified through the literature review preceding the research presented in this article. Baker [20], however, analyzed the effect mortar flow has on the bond strength of brickwork. They concluded that ' $[t]$ he flow of mortar is a sensitive and important parameter influencing the flexural-bond strength of brickwork. Maximum strength is obtained with mortars of wettest workable consistency' (p. 86). This analysis lies, in fact, very close to the research reported on in this article. Baker [20] uses, however, terms like 'the wettest workable mix' and 'the driest workable mix' without reporting on the specific flow of the mortar employed. In addition, the IRA of the brick used by Baker [20] is high $\left(3.2 \mathrm{~kg} / \mathrm{m}^{2} / \mathrm{min}\right)$. These analyses do not address questions concerning resistance to rain penetration and deviate from the most common brick properties within the Norwegian context (IRA approx. $1.0 \mathrm{~kg} / \mathrm{m}^{2} / \mathrm{min}$.).

A recent study by Costigan and Pavia [21] uses bricks with an IRA of $1.0 \mathrm{~kg} / \mathrm{m}^{2} / \mathrm{min}$; that is, similar to Norwegian conditions. Their findings and conclusions none the less coincide with those of Baker [20]. Costigan and Pavia [21] focused on low-flow valued difference mortars (165 mm versus $170 \mathrm{~mm}$ flow). The analysis presented lacks, however, any operational analysis of what the actual flow variation can be in workplace conditions. In addition, their analysis focused on lime-based mortar and not on cement-based mortar (being most commonly used within the Norwegian Architecture, Engineering and Construction (AEC) Industry). Neither do they consider resistance to rain.

\subsection{The Influence of Impregnation of Clay Brick Masonry on Driving Rain Resistance}

As mentioned in the introduction, water repellents seem to work well with bricks (masonry units). Masonry (structurally assembled) with cracks and pores on the other hand is problematic. Water-repellent (WR) treatments are non-film and non-crack-bridge forming. As early as 1963, Hutcheon [22] concluded that silicone masonry water repellents are unable to prevent water from entering though cracks and large pores. Equally, he maintained that the rate of evaporation may decrease and walls could be worse off with regard to freeze-thaw cycles. The conclusion that impregnation could be destructive has since been shared in full or partially by others $[9,23,24]$. Table 1 provides an overview of four common types of WR impregnation products.

Table 1. Types of water-repellent impregnation.

\begin{tabular}{|c|c|c|c|c|}
\hline Water Repellent & $\begin{array}{l}\text { Water Vapour } \\
\text { Transmission }\end{array}$ & $\begin{array}{c}\text { Water } \\
\text { Repellence }\end{array}$ & $\begin{array}{l}\text { Service } \\
\text { Life Years }\end{array}$ & Characteristic \\
\hline Silicone (resins) & Fair [23] & Varies [23] & $1[23]$ & Low resistance to alkaline building materials [25] \\
\hline Silane & Very good [23] & Very good [23] & $10+[23]$ & $\begin{array}{l}\text { Highly volatile. Reacts with moisture to form its } \\
\text { water repellent characteristics. } \\
\text { Composed of smaller molecules and, therefore, } \\
\text { can penetrate deeper into the masonry. Alkali } \\
\text { resistant. Effectiveness depends on the presence } \\
\text { of alkaline materials [25] }\end{array}$ \\
\hline Siloxane & Very good [23] & Very good [23] & $10+[23]$ & $\begin{array}{l}\text { Contains a built-in catalyst, reducing } \\
\text { dependency on alkaline materials for } \\
\text { effectiveness. Can penetrate deeply into the } \\
\text { masonry substrate. Evaporates slower than } \\
\text { silanes [25] }\end{array}$ \\
\hline Nano & Excellent [26] & Very good [26] & $\mathrm{N} / \mathrm{A}$ & $\begin{array}{l}\text { Show similar properties as traditional } \\
\text { silane-siloxane products with respect to reducing } \\
\text { water ingress. Affect drying of the material much } \\
\text { less than traditional products [26] }\end{array}$ \\
\hline
\end{tabular}




\subsection{Knowledge Gap}

Some studies have been carried out on different mortar and brick qualities. None have been identified, however, that consider the relationship between water content in fresh mortar and resistance to driving rain. Equally, the influence of impregnation to driving rain resistance seems to have been little scrutinized. For impregnation, the effect on bricks and mortar is known, also with regards to durability (especially under freeze-thaw conditions). The rain penetration resistance of veneers before and after impregnation seems, however, to have been largely unscrutinised. The study reported on in this paper addresses precisely these knowledge gaps.

\section{Materials and Methods}

\subsection{Material Selection and Properties}

Mortar and bricks were selected to best represent a typical Norwegian brick veneer wall. The mortar is a Portland cement (with some lime for workability) named Weber M5. This is the most used mortar in Norway. The bricks are Haga red perforated clay bricks from Wienerberger. Impregnation was chosen to test the four principal types of masonry water-repellent (WR) treatment, notably silicone, silane, siloxane, and nano-particulate. The materials are presented in Tables 2 and 3.

Table 2. Masonry materials.

\begin{tabular}{cccc}
\hline Material & Name & Producer & Details \\
\hline Clay brick & Haga red & Wienerberger & WA 8\% [27], IRA 1.0 kg $/ \mathrm{m}^{2} / \mathrm{min}$ * \\
\hline Masonry mortar & M5 & Weber & $\begin{array}{c}\text { Portland Cement 11.7\%, Lime 1-5\%, Filler 11.4\%, } \\
\text { Chemicals 0.5\% Natural sand 0-2 mm 60-100\% [28,29] }\end{array}$ \\
\hline
\end{tabular}

* Water absorption (WA )is a declared valuel the initial rate of absorption (IRA) was measured.

Table 3. Water-repellent impregnation materials.

\begin{tabular}{ccc}
\hline Material & Name & Producer \\
\hline Silicone WR & Aquasil & Hey'di \\
Silane WR & Planisil WR-100 & Mapei \\
Siloxane WR & 1..2..fugeimpreg & Mira \\
Waterbased nano WR & SurfaPore C & SurfaProducts Scandinavia \\
\hline
\end{tabular}

\subsection{Building and Impregnation of Panels}

Four panels were built with different mortar flow and workmanship techniques as variables. Panels named A, B, and C were built using low, medium, and high water content mortar. The cases addressed in this article all fall within the recommendations of the mortar producer. The range of mortar consistency is thus not arbitrary but follows accepted standards. The factor of driving rain penetration is thus generalizable.

The building of $\mathrm{A}, \mathrm{B}$, and $\mathrm{C}$ was done using the recommended workmanship technique of buttering. Panel $\mathrm{D}$ was built with high water content like $\mathrm{C}$ but with another workmanship technique, notably that of pushing head joints. Different batches of the same mortar gave considerable variation in consistency with precisely the same dry mortar to water ratio. Therefore, even though water content was the variable we wanted to investigate, the mortar was judged by consistency, i.e., the flow table value rather than the amount of water. The flow value of the panels were A $135 \mathrm{~mm}, \mathrm{~B} 174 \mathrm{~mm}$, $\mathrm{C}$ and D $186 \mathrm{~mm}$. Thus, water content, flow and consistency can be seen as synonymous in the following. This might not be the case in other study designs since mortar composition or additives can change the consistency while keeping water content constant. Also, consistency could include properties of the mortars rheology other than only the flow table value. 
The panels tested were $990 \mathrm{~mm} \times 990 \mathrm{~mm}$. The exposed front of the panels after mounting in frames was $950 \mathrm{~mm} \times 950 \mathrm{~mm}$; the joints were on average $13 \mathrm{~mm}$ for both bed and head joints, with a brushed concave finish. Bricks for adjustment were cut with a mason's brick chisel. The construction of the panels was carried out in order to simulate real on-site conditions. More precisely, this means that the panels were built between fixed corner poles from the front side only, and, after completion, excess mortar was removed. The panels were built and cured for 28 days ( 27 for B and D) in laboratory air, uncovered. The average temperature in the laboratory was $19.8^{\circ} \mathrm{C}$ with a standard deviation of $0.5^{\circ} \mathrm{C}$, whereas the average relative humidity was $21.5 \%$, with a standard deviation of $7.3 \%$. After the first round of rain testing, the panels were dried for 11 weeks and then impregnated according to the producer's recommendations. The panels were dried after exposure in laboratory climate conditions. A fan (using in-situ laboratory air) was used to quicken the process. The drying period of 11 weeks was chosen on pragmatic grounds, with the objective of rendering the specimens (the brick panels) to the same weight as they had prior to the first rain exposure. See Table 4 for details on the application of impregnation.

Table 4. Application of impregnation.

\begin{tabular}{|c|c|c|c|c|c|}
\hline WR & Panel & Coats * & $\begin{array}{c}\text { Drying } \\
\text { between Coats }\end{array}$ & $\begin{array}{c}\text { Recommended } \\
\text { Consumption }\end{array}$ & $\begin{array}{c}\text { Actual } \\
\text { Consumption }\end{array}$ \\
\hline Aquasil & A & 2 & $2.5 \mathrm{~h}$ & $0.2-0.4 \mathrm{~L} / \mathrm{m}^{2}$ & $0.30 \mathrm{~L} / \mathrm{m}^{2}$ \\
\hline Planisil WR-100 & B & 2 & $10 \mathrm{~min}$ & $0.1-0.2 \mathrm{~L} / \mathrm{m}^{2}$ & $0.15 \mathrm{~L} / \mathrm{m}^{2}$ \\
\hline 1..2..fugeimpreg & $\mathrm{C}$ & 2 & None & $0.10-0.05 \mathrm{~L} / \mathrm{m}^{2}$ & $0.15 \mathrm{~L} / \mathrm{m}^{2}$ \\
\hline SurfaPore C & $\mathrm{D}$ & 1 & - & $0.13-0.10 \mathrm{~L} / \mathrm{m}^{2}$ & $0.11 \mathrm{~L} / \mathrm{m}^{2}$ \\
\hline
\end{tabular}

${ }^{*}$ Both the recommended and applied number of coats.

\subsection{Test Procedure NBI 29/1983}

The tests were carried out in a driving rain chamber in accordance with NBI method 29/1983 [30] (internal SINTEF building and infrastructure method). The panels were assembled in the opening of the apparatus, with the exposed side facing inwards into the chamber. A joint sealant (tape) was used to seal the joint between the chamber and the panels' frames. A determination of driving rain resistance was carried out according to the following exposure procedure:

- The panels were subjected to five hours with a static overpressure of $750 \mathrm{~Pa}$ (corresponding to wind with hurricane force) and sprayed with water $1.2 \mathrm{~L} /\left(\mathrm{m}^{2} \mathrm{~min}\right)$. The spraying of water was located at the upper part of the test panels, in the third course from the top;

- The panels were subjected to five hours without air pressure and with spraying water but with a stream of air on the panel surface (fan continues to operate, cabinet is opened);

- The panels were subjected to thirty-six hours with a static overpressure of $750 \mathrm{~Pa}$ and sprayed with water of $1.2 \mathrm{~L} /\left(\mathrm{m}^{2} \mathrm{~min}\right)$.

The test procedure includes monitoring the panels during testing. Here the panels were photographed every $5 \mathrm{~min}$, resulting in time-lapse videos. In the testing of the unimpregnated panels, they were monitored in person for the first two hours. In the testing of the impregnated panels, sporadic in-person monitoring was carried out. The weighing of panels before and after was also carried out according to the procedure.

\subsection{Assessment of Water Penetration Following Driving Rain}

The procedure used to assess water penetration following driving rain is not standardized or previously described, although the collection and measuring of water that penetrates a masonry wall has been carried out previously $[17,31]$. The aim was to collect solely the water that went through the panel, avoiding water that was running down on the inside of the panel or took the shortcut around 
the sealant in the corners. Following visual observation of the panels being completely soaked, the penetrating water was collected. Troughs were folded from heavy-duty aluminium foil slightly longer than the panels, $30 \mathrm{~mm}$ wide and $50 \mathrm{~mm}$ high. They were placed underneath the backside of the panels. See the principle cross section illustration in Figure 3. A period of $20 \mathrm{~min}$ was found to be the best practical compromise between not overfilling (reducing the risk of spilling) and still having sufficient water to minimize the measurement error by the water left in the troughs after emptying them into the measuring cups. The amount of water was assessed in the same measuring cup. This was found to be sufficiently accurate for comparing the different panels.

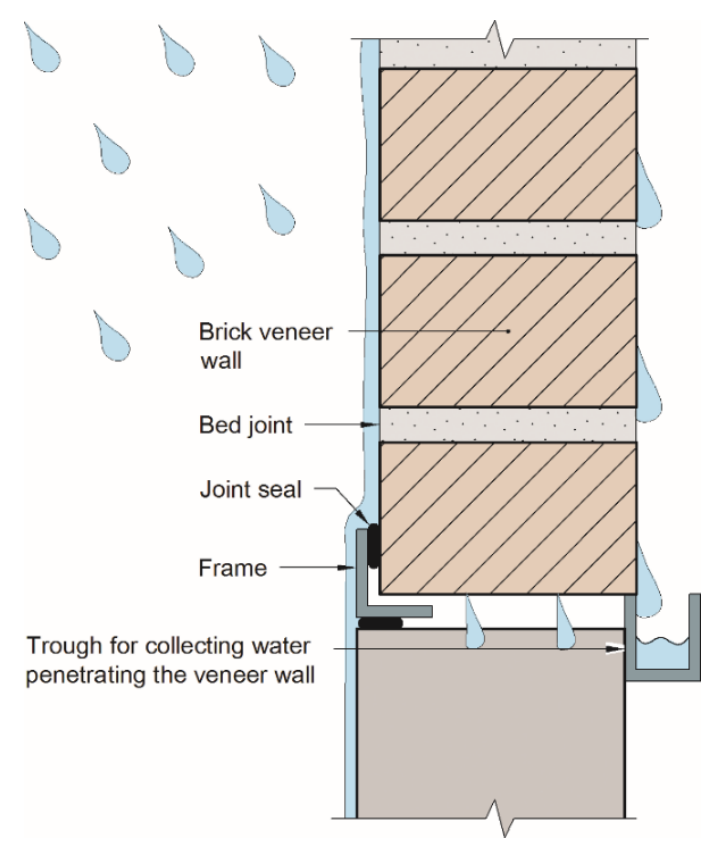

Figure 3. Collecting water, principal cross-section.

\subsection{Thin Sections}

Three thin sections (A, B, and C) of $48 \mathrm{~mm} \times 28 \mathrm{~mm}$ were prepared from masonry built with approximately the same flow table values (A $148 \mathrm{~mm}$, B $165 \mathrm{~mm}$, and C $196 \mathrm{~mm}$ ) as for the wall panels. The preparation of the thin sections was carried out by the Thin Section Laboratory at the Norwegian University of Science and Technology. The preparation included fluorescence impregnation and polishing. Microscopy analysis with UV filters was performed with Nikon, ECLIPSE LV 100 POL, Tokyo, Japan. This analysis equally included the measurement of actual contact between the bricks and the mortar (bond) and a visual assessment of the density of the mortar.

\subsection{Influence of Workmanship}

From professional experience and from the previously mentioned building site visits, it is known that pushing the head joint is a common technique in Norway. This stands in contrast to the recommended technique, which is to butter the end of bricks prior to laying to ensure full joints [13]. The recommended technique is used for all three mortar mixes (panels A, B, and C). To evaluate the influence of workmanship, panel $\mathrm{D}$ was built by pushing the head joints. The only difference between $\mathrm{C}$ and $\mathrm{D}$ was the technique used to fill the head joints. 


\section{Results}

\subsection{Water Penetration}

The main results are based on visual observations, seeing when, where, and how much water penetrated the panels; see Figure 4. The authors recommend seeing the time-lapse videos documenting the procedure, to which a link is included in the Supplementary Materials section. The panels were first tested without any form of coating and later impregnated with four types of WR; see Table 3.

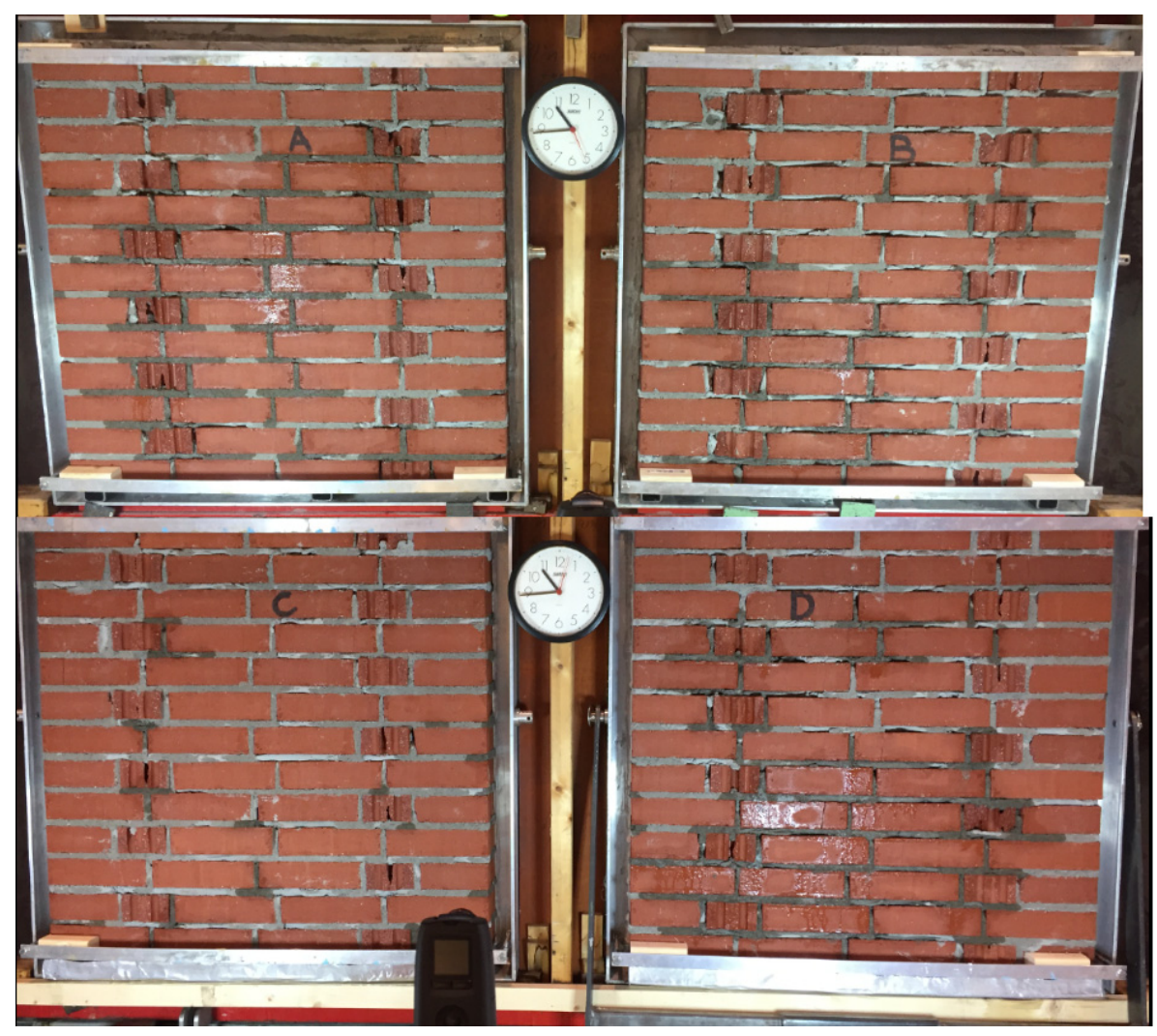

Figure 4. Panels A, B, C, and D after 45 min of simulated driving rain.

First presented, in Figure 4 and in the upper part of Table 5, are the results for the untreated panels. Panel $C$ is clearly better than the others; in order of best to worst performance, the panels in Figure 4 appear in the order C, B, A, and D. The first or major points of leakage seem to be somewhat randomly distributed. Even so, some assumptions can be made from knowledge about the panels and observation of the test. The panels were built between corner poles. Consequently, there was no room to compress the last joint on each course. The last joint can be seen on the left (back) side of the panels in Figure 4. All panels show signs of leaking more easily at the last joint. A corner pole or the meting point between two masons would be the equivalent on a construction site. It also looks like the head joints are worse than the bed joints. An exception is panel D, where the bed joints appear to be somewhat worse than for the other panels. This implies that taking mortar from bed joints to fill head joints has a negative impact on the bed joint.

Prior to testing, it was expected that the incomplete filling of mortar in some of the joints could create weak points. This appears, however, not to be the case. It can be seen in Figure 4 that the joints are not completely filled on the backside of the panels. Even by means of careful observation it was not possible to observe any additional weakness in these areas.

From visual inspection during testing, the impregnated panels showed some resilience to the wetting of the façade surface, confirming that they were to some degree water repellent. Table 5 shows 
that all panels were, in fact, more resistant to rain penetration in the early stages of the test. Even so, both the visual results in Table 5 and the measuring of water passing through the panels in Table 6 indicate little to no improvement in the water-tightness of the panels, stemming from impregnation with water-repellent silicone, silane siloxane, or nanoparticulated.

Table 5. Wetting of the backside of panels [\%].

\begin{tabular}{|c|c|c|c|c|c|c|c|c|c|c|c|c|}
\hline \multirow{2}{*}{ Time State ${ }^{1}$} & \multicolumn{3}{|c|}{ Panel A } & \multicolumn{3}{|c|}{ Panel B } & \multicolumn{3}{|c|}{ Panel C } & \multicolumn{3}{|c|}{ Panel D ${ }^{2}$} \\
\hline & D & $\mathbf{M}$ & W & D & $\mathbf{M}$ & $\mathbf{W}$ & D & $\mathbf{M}$ & $\mathbf{W}$ & D & $\mathbf{M}$ & $\mathbf{W}$ \\
\hline $5 \mathrm{~min}$ & 95 & 5 & 0 & 95 & 5 & 0 & 95 & 5 & 0 & 85 & 10 & 5 \\
\hline $15 \mathrm{~min}$ & 90 & 5 & 5 & 90 & 10 & 0 & 95 & 5 & 0 & 80 & 15 & 5 \\
\hline $30 \mathrm{~min}$ & 80 & 10 & 10 & 85 & 10 & 5 & 90 & 10 & 0 & 70 & 20 & 10 \\
\hline $1 \mathrm{~h}$ & 60 & 20 & 20 & 70 & 15 & 15 & 90 & 10 & 0 & 55 & 25 & 20 \\
\hline $2 \mathrm{~h}$ & 25 & 40 & 35 & 50 & 30 & 20 & 85 & 10 & 5 & 40 & 30 & 30 \\
\hline $5 \mathrm{~h}$ & 15 & 20 & 65 & 30 & 45 & 25 & 65 & 20 & 15 & 15 & 15 & 70 \\
\hline$<5 \% \mathrm{D}$ & \multicolumn{3}{|c|}{$6 \mathrm{~h} 20 \mathrm{~min}$} & \multicolumn{3}{|c|}{8 h 25 min } & \multicolumn{3}{|c|}{11 h $50 \mathrm{~min}$} & \multicolumn{3}{|c|}{$5 \mathrm{~h} 25 \mathrm{~min}$} \\
\hline \multirow{2}{*}{ Time State ${ }^{1}$} & \multicolumn{3}{|c|}{ A silicone } & \multicolumn{3}{|c|}{ B silane } & \multicolumn{3}{|c|}{ C siloxane } & \multicolumn{3}{|c|}{ D nano-particulate } \\
\hline & D & $\mathbf{M}$ & W & D & $\mathbf{M}$ & W & $\mathbf{D}$ & $\mathbf{M}$ & W & D & $\mathbf{M}$ & W \\
\hline $5 \mathrm{~min}$ & 100 & 0 & 0 & 100 & 0 & 0 & 100 & 0 & 0 & 100 & 0 & 0 \\
\hline $15 \mathrm{~min}$ & 90 & 5 & 5 & 90 & 10 & 0 & 100 & 0 & 0 & 95 & 5 & 0 \\
\hline $30 \mathrm{~min}$ & 80 & 15 & 5 & 80 & 15 & 5 & 95 & 5 & 0 & 90 & 10 & 0 \\
\hline $1 \mathrm{~h}$ & 45 & 35 & 20 & 50 & 40 & 10 & 95 & 5 & 0 & 75 & 20 & 5 \\
\hline $2 \mathrm{~h}$ & 15 & 45 & 40 & 20 & 65 & 15 & 95 & 5 & 0 & 30 & 65 & 5 \\
\hline $5 \mathrm{~h}$ & 10 & 55 & 35 & 10 & 80 & 10 & 85 & 10 & 5 & 15 & 75 & 10 \\
\hline$<5 \% \mathrm{D}^{3}$ & \multicolumn{3}{|c|}{$6 \mathrm{~h} 30 \mathrm{~min}$} & \multicolumn{3}{|c|}{$7 \mathrm{~h} 25 \mathrm{~min}$} & \multicolumn{3}{|c|}{$13 \mathrm{~h} 0 \mathrm{~min}$} & \multicolumn{3}{|c|}{$5 \mathrm{~h} 45 \mathrm{~min}$} \\
\hline
\end{tabular}

${ }^{1}$ State describes dy (no sign of moisture), moist (dark fields/spots), and wet (visible free water, shiny surface); the values are visually derived from the time lapse videos, with accuracy limited to $5 \%{ }^{2}$ Note that panel D has been built by pushing the head joints, unlike the rest of the panels, wherein the mortar for the head joints was placed on the brick prior to laying; ${ }^{3}$ Time until more than $95 \%$ of the backside surface is wet or moist.

Table 6. Water penetration towards the end of the testing.

\begin{tabular}{ccccc}
\hline Comments & Panel A & Panel B & Panel C & Panel D \\
\hline Flow $-\mathrm{mm}$ & 135 & 174 & 186 & 186 \\
Penetration - $1 / \mathrm{h} \cdot \mathrm{m}^{2}$ & 1.14 & 0.97 & 0.14 & 0.67 \\
Water-repellent & Silicone & Silane & Siloxane & Nano-particulate \\
Treated penetration & 1.15 & 1.38 & 0.06 & 0.50 \\
\hline
\end{tabular}

Weighing before and after testing forms part of NBI method 29/1983 [30], and the results are presented in Table 7. All panels were soaking wet after the completion of the test procedure so the results do not provide much information except from the mass increase $(\approx 115 \mathrm{~N})$. This accords well with the panel size and the declared water absorption of the bricks ( $8 \%$ see Table 2$)$.

Table 7. Mass gain of panels $[\mathrm{N}]$.

\begin{tabular}{ccccc}
\hline Finishing & Panel A & Panel B & Panel C & Panel D \\
\hline Untreated & 138 & 98 & 111 & 109 \\
Impregnated & 111 & 107 & 117 & 115 \\
\hline
\end{tabular}

The prescribed breaking of the panels in accordance with NBI method 29/1983 [30], carried out to measure how far the water has penetrated, was not carried out since the panels clearly were wet all the way through. 
According to the different suppliers, all the tested WRs are supposed to be transparent and were in fact invisible after application. After testing, it looked like all the panels had a weak brown/yellow discoloration of the three upper joints. These joints were above the water spraying heads during testing. Also, panel A and panel B have rust brown deposits running down their walls from some of the ITZ between the brick and mortar; see the example in Figure 5a. A simple spray test to evaluate water repellence was performed. All panels proved to be water repellent, and all panels absorbed some water. Ranking the WRs from best to worst based on visual impressions gave the following order: Nano was best, Silane and Siloxane were similar, and Silicone had the poorest performance. Figure $5 \mathrm{~b}$ shows a part of panel $\mathrm{D}$ (Nano) during spray testing.

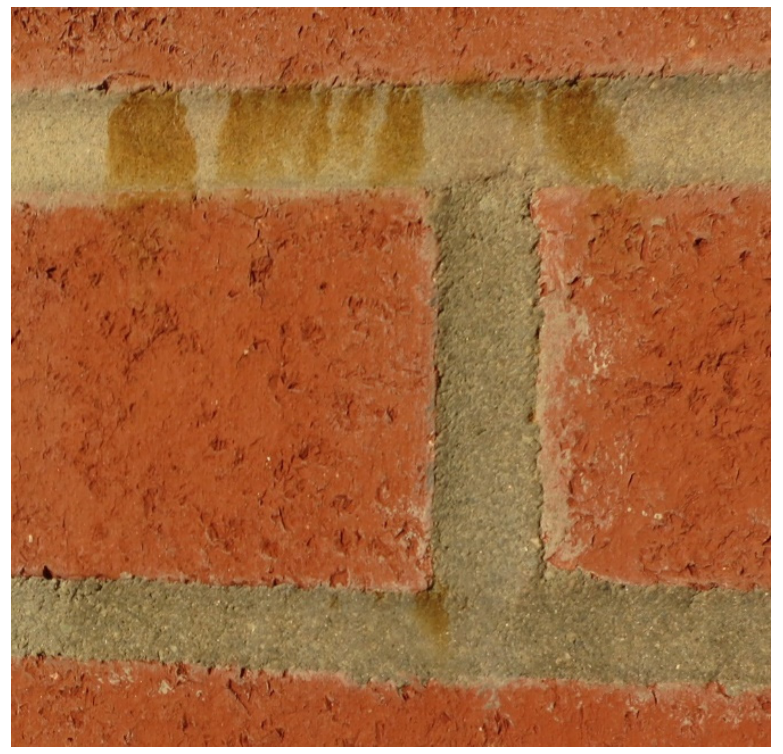

(a)

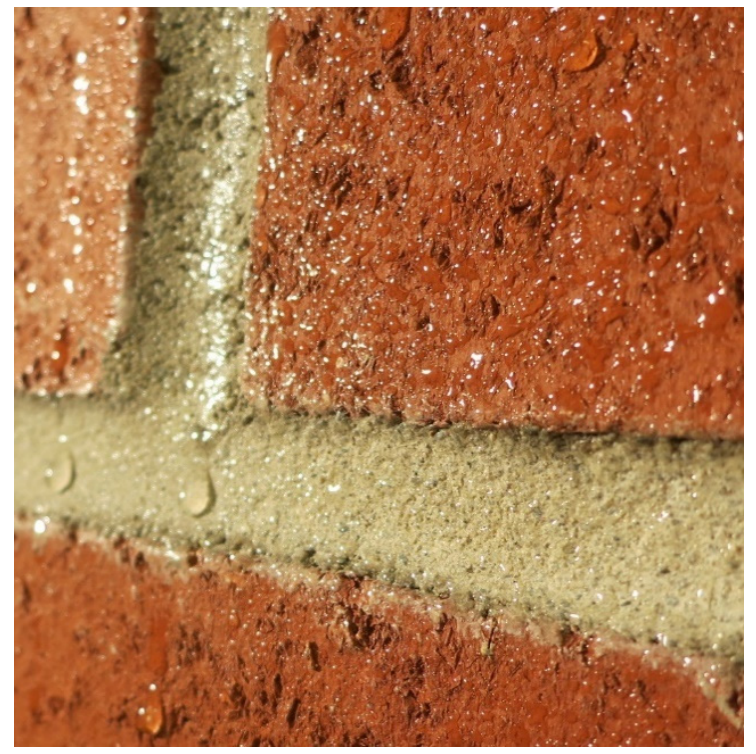

(b)

Figure 5. (a) Rust brown deposits from the ITZs of panel B after drying; (b) Water repellency of panel D.

\subsection{Microscopy Analysis of Thin Sections}

The quality of the interface between the brick and the mortar differs between the three thin sections; see Table 8 . In the areas without contact, elongated air voids and some cracks were observed. The samples made from masonry with dry and medium mortar both had one interface (brick to mortar), loosened during the preparation of the thin sections.

Table 8. Contact in/on the brick and mortar interface.

\begin{tabular}{cccc}
\hline Thin Section & Dry & Medium & Wet \\
\hline Upper ITZ of joint & Fracture & Fracture & $35 \%$ \\
Lower ITZ of joint & $10 \%$ & $20 \%$ & $50 \%$ \\
\hline
\end{tabular}

In the dry sample, a somewhat lower porosity can be observed in the mortar from the interface of the brick surface to a maximum of $0.4 \mathrm{~mm}$ from the brick. The reason for this is most likely that the brick has sucked water from the mortar during the hydration process. This phenomenon can hardly be observed for the medium water content sample and not at all for the wet sample.

Figure 6 is an example of an area with good bond and where the contact zone between the mortar (on top) and the brick (bottom, dark area) is good. Good contact between mortar and brick leaves less pores for water to penetrate. In Figures 6 and 7, the yellow parts are air voids, filled with yellow epoxy. Both Figures 6 and 7 are made from samples that were built using wet mortar. Figure 6 illustrates good 
contact between mortar and bricks. Figure 7 show large, elongated air voids in the ITZ, where water easily can penetrate.

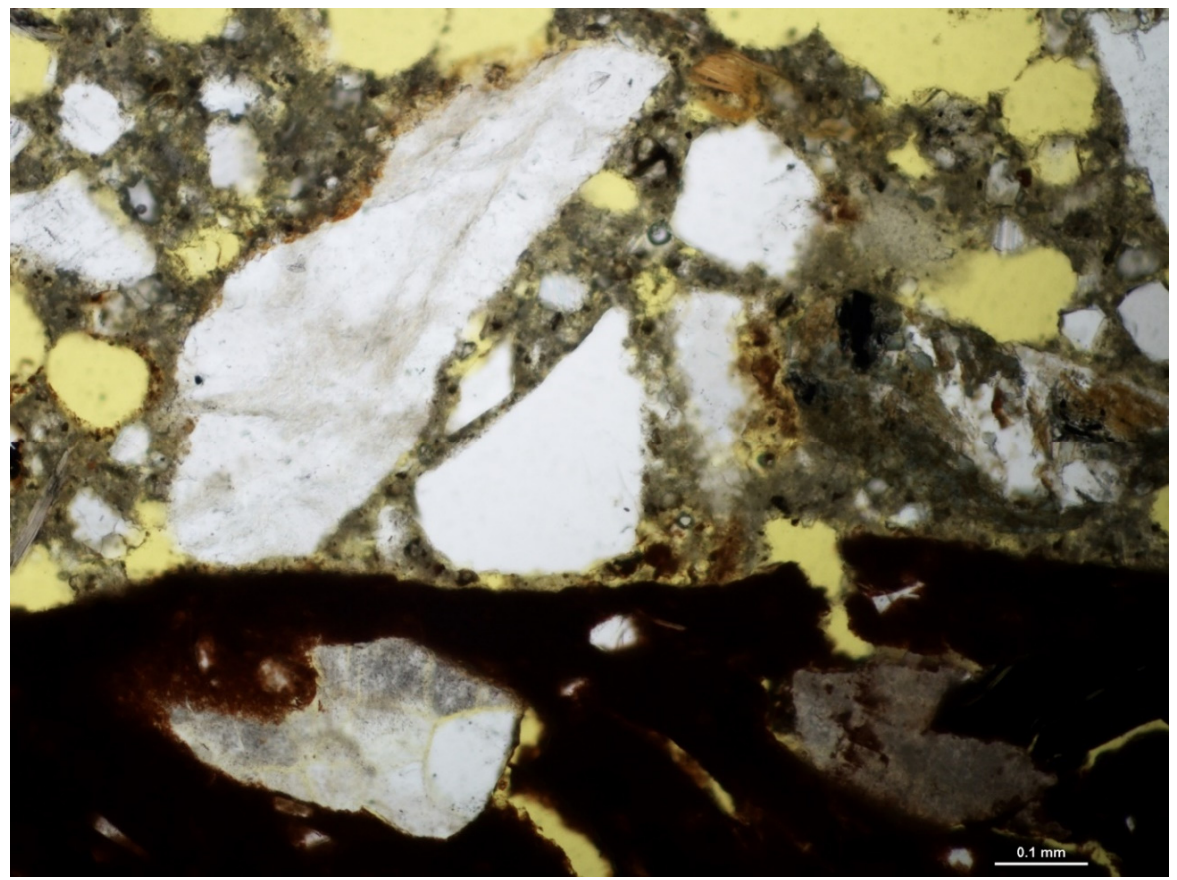

Figure 6. Microscopy image of a thin section; an area with good contact. The yellow parts are air voids, whilst the white parts are aggregate, and the contact zone is the interface between the dark and the charcoal-coloured cement paste.

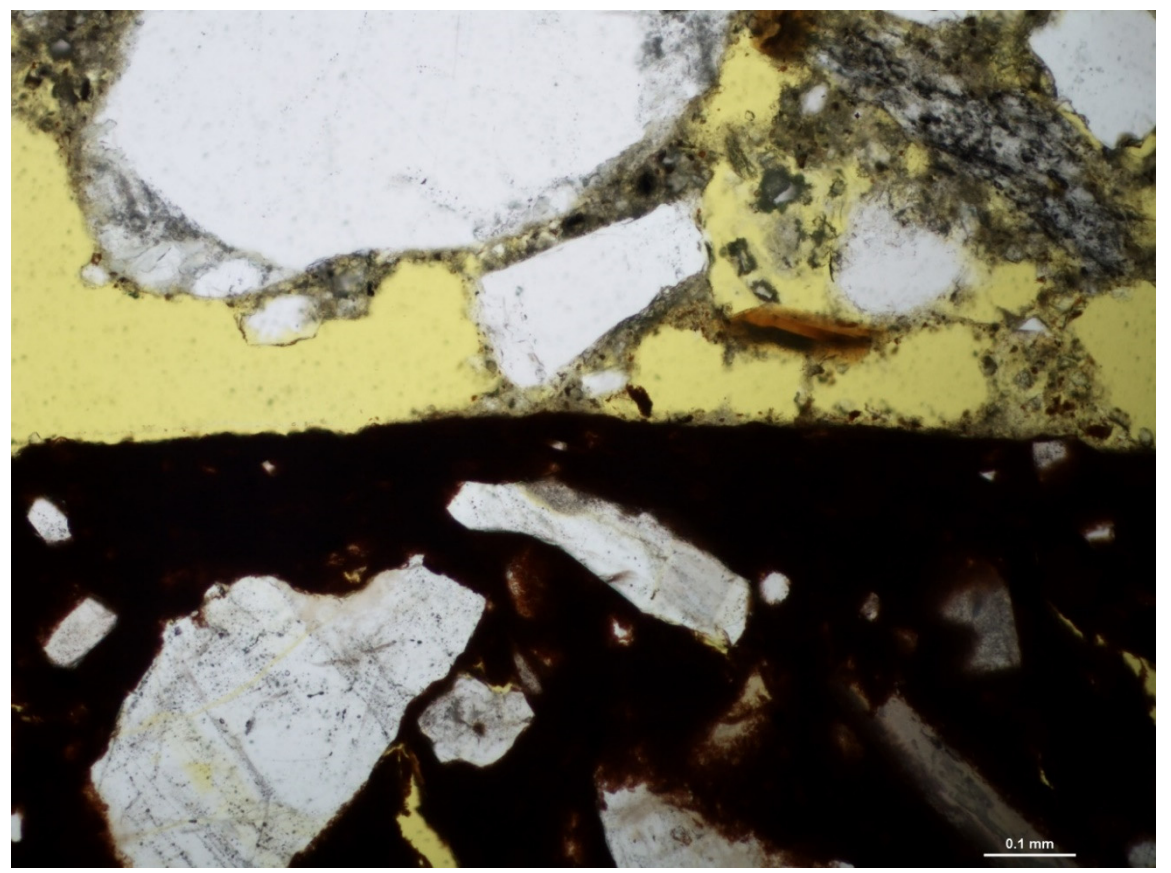

Figure 7. Microscopy image of a thin section; an area with large, elongated air voids. The yellow parts are air voids, whilst the white parts are aggregate, and the contact zone is the interface between the dark and the charcoal-coloured cement paste. 


\section{Discussion}

The research reported on in this paper set out to find (1) the influence of fresh mortar water content on the resistance to driving rain of un-impregnated masonry and (2) the influence of impregnating masonry against driving rain. The following discussion is organised according to this.

\subsection{The Influence of Fresh Mortar Water Content}

Using wet masonry mortar has been shown to be effective in achieving good bonding between mortar and brick, thus strongly reducing water permeability and improving the resistance to driving rain. This appears to contradict Bowler et al. [19], maintaining that a smaller flow table spread would be more resistant to driving rain penetration. By measuring flow at a constant consistency (measured by a plunger), Bowler et al. [19] measured the properties of the mortar itself rather than the effect of added water. Therefore, both conclusions could be sound, and the combined conclusion would be that masonry mortar should have both good cohesion and a high flow value.

Placing mortar consistency in a broader context, it seems probable that changing from dry to wet mortar would lead to reducing moisture related defects and decay, improving structural properties and, according to the experience of the main author, an increased pace of building. The disadvantages could be challenges in achieving aesthetic quality equal to that obtained by using dry mortar since wet mortar increases spilling and the need for the cleaning of new walls.

According to the analysis, workmanship techniques seem to be significant. Table 5 shows that the untreated panel D had the poorest early stage performance of all panels. This is so, even if it was built with the same wet mortar as panel $C$, which was the best in all aspects. This indicates that using the recommended technique of buttering the bricks can significantly improve the masonry quality. Due to only one panel having been built by pushing the head joint, the research reported in this article is not sufficient to make general recommendations concerning workmanship. Einstadblad and Westbye [31] found in their tests of workmanship techniques that buttering was better for red bricks (IRA $1.0 \mathrm{~kg} / \mathrm{m}^{2} / \mathrm{min}$ ) but not for yellow bricks (IRA $4.0 \mathrm{~kg} / \mathrm{m}^{2} / \mathrm{min}$ ). Their conclusion was that the most important factor was the mason's professional pride or work ethic. Their masonry techniques (especially in that the mortar used was drier than what is used in the research reported on in this paper) differ in a manner that renders comparison challenging. None the less, we agree that these are important factors. Even so, we maintain that knowledge about other more specific factors is equally important. Amongst these, knowledge of mortar water content and workmanship is essential both for practitioners seeking to deliver the best they can and for imposing quality standards.

\subsection{The Influence of Impregnating Masonry}

Hydrophobic impregnation reduced water penetration in all four tested WRs in the first minutes. After this, no measurable improvement could be observed. The observed failure to reduce water permeability could, to some extent, be due to the extreme conditions of the testing procedure, especially the overpressure of $750 \mathrm{~Pa}$ (equal to hurricane wind speed). Such conditions have earlier been shown to influence the performance of rendered masonry compared to testing without overpressure [32].

Since the WRs were tested on substantially different panels, there is no basis for the evaluation of the different WRs against each other. The ambition here was not, however, to quantify or compare different impregnation solutions but rather to assess the possible potential for improving the driving rain resistance of masonry using impregnation.

Both the abilities of the specific WR and the properties of the panel could contribute to the recorded performance. Testing WRs on similar panels with a more realistic wind load would be beneficial in evaluating their performance. Figure 7, with large, elongated air voids of around $200 \mu \mathrm{m}$, can explain why the WRs are unable to increase the resistance to driving rain. Impregnated veneers allow moisture to enter and hinders it from escaping. Water retained in the masonry increases the risk of frost deterioration, as reported by Šadauskienè et al. [9], and salt eruption, as described by Ioannou 
and Hoff [33]. Blom [6] recommend using WR impregnation on masonry veneers, stating that it will efficiently reduce moisture in veneer walls and reduce the moisture load on the internal part of the wall. He does, however, question the efficiency if the wall has cracks that can lead to capillary suction of water into the wall. Based on the driving rain test and the thin section analysis, we find it reasonable to assume that the ITZ between mortar and brick masonry does in fact have air voids that cannot be protected from moisture ingress by applying WR impregnation.

\section{Conclusions}

High flow, i.e., high water content masonry mortar, strongly improves masonry veneers' resistance to driving rain, even for low to moderate IRA bricks. Within the workable range of mortar consistency, more water unequivocally provides improved results. The test results presented in this article show that mortar with low water content gives a porous ITZ, thereby increasing the rate of water penetration.

According to the test results, WR treatment cannot be expected to improve masonry veneers' resistance to high pressure driving rain. The results reported in this article, combined with what is already known about WR treatments on masonry, call for careful consideration before applying such treatment. This proves especially true in Norway and other countries with much driving rain followed by frequent freeze-thaw cycles.

Supplementary Materials: The following are available online at https://drive.google.com/file/d/ 0B5fyJKDetSPUM1RqOEoxa3hZWW8/view?usp=drive_web. Videos: S1 Time-lapse of Untreated A and B, S2 Time-lapse of Untreated C and D, S3 Time-lapse of Silicone A and Silane B, S4 Time-lapse of Siloxane C and Nano D.

Acknowledgments: We would like to present our gratitude to Klima 2050 as the founding participant of the research presented in this article. Likewise, Weber has been very welcoming. A special thanks to CAD operator Remy Eik.

Author Contributions: Fredrik Slapø initiated and carried out the main bulk of the research. The research has been conducted according to his initial ideas, concerning the problem to be addressed, the research design, and the test program. He has been responsible for the literature review and the carrying out of the main part of the laboratory work and has been the main person responsible for drafting the article. Tore Kvande has served as the main supervisor during the process and has, together with Noralf Bakken, contributed in the design of the research program and in the analysis and interpretation of the results. Noralf Bakken initiated the impregnation part of the study and has, together with Fredrik Slapø, been responsible for the performance of the rain testing. Marit Haugen has executed the thin sections analysis. Jardar Lohne contributed to the research design and has been responsible for an efficient scientific writing process and the analytic cohesion of the analysis. All the co-authors have provided critical comments on the prepared manuscript by Fredrik Slapø during the process, and they have all given final approval of the version to be published.

Conflicts of Interest: The authors declare no conflict of interest.

\section{References}

1. IPCC. Climate Change 2014: Synthesis Report. In Contribution of Working Groups I, II and III to the Fifth Assessment Report of the Intergovernmental Panel on Climate Change; Core Writing Team, Pachauri, R.K., Meyer, L.A., Eds.; IPCC: Geneva, Switzerland, 2014; p. 10.

2. Andreassen, L.M.; Beldring, S.; Bjune, A.; Breili, K.; Dahl, C.A.; Dyrrdal, A.V.; Isaksen, K.; Haakenstad, H.; Haugen, J.E.; Hygen, H.O.; et al. Klima i Norge 2100-Kunnskapsgrunnlag for klimatilpasning oppdatert i 2015 (Knowledge basis for climate adaption updated version 2015). NCCS Report No. 2/2015. Available online: https:/ / cms.met.no/site/2/klimaservicesenteret/rapporter-ogpublikasjoner/_attachment/6616?_ts=14ff3d4eeb8 (accessed on 4 June 2017).

3. Lisø, K.R. Building Envelope Performance Assessments in Harsh Climates: Methods for Geographically Dependent Design. Ph.D. Thesis, Norwegian University of Science and Technology, Trondheim, Norway, 2006.

4. Lisø, K.R.; Kvande, T.; Thue, J.V. Learning from experience-An analysis of process induced building defects in Norway. In Proceedings of the 3rd International Building Physics/Science Conference, Montreal, QC, Canada, 27-31 August 2006. 
5. Lisø, K.R.; Kvande, T.; Hygen, H.O.; Thue, J.V.; Harstveit, K. A frost decay exposure index for porous, mineral building materials. Build. Environ. 2007, 42, 3547-3555. [CrossRef]

6. Blom, P. Fuktsikker innvendig etterisolering av mur- og betongvegger (Moisture safe internal insulation on existing masonry and concrete walls). In SINTEF Fag Prosjektrapport; SINTEF: Oslo, Norway, 2014; Volume 22, ISBN 978-82-536-1404-5.

7. Stefanidou, M.; Karozou, A. Testing the effectiveness of protective coatings on traditional bricks. Constr. Build. Mater. 2016, 111, 482-487. [CrossRef]

8. Defreece, N.; Charola, E. Coatings on Brick Masonry: Are They Protective or Can They Enhance Deterioration? J. Am. Inst. Conserv. 2007, 46, 39-52.

9. Šadauskienė, J.; Ramanauskas, J.; Stankevičius, V. Effect of Hydrophobic Materials on Water Impermeability and Drying of Finish Brick Masonry. Mater. Sci. 2003, 9, 94-98.

10. NS 3420-N:2012. Specification texts for building, construction and installations Part N: Masonry and rigid tile work. Standard, Norway, 2012. Available online: http://www.standard.no/no/Nettbutikk/ produktkatalogen/Produktpresentasjon/?ProductID=588807 (accessed on 7 August 2017).

11. Rocky Mountain Masonry Institute. Mortar Joints-How Full is Full? Masonry Tech Memo 1996, 1, 1-2.

12. Kvande, T. Murt forblending (masonry veneers). In SINTEF Building Research Design Guide 542.301; SINTEF: Oslo, Norway, 2013.

13. Madsø, F.E.; Wold-Hansen, G.; Høiby, A. Murkatalogen Anvisning P1 Skallmurvegger (Masonry Catalog-Guide P1 Masonry Veneers); Mursenteret: Oslo, Norway, 1998.

14. Blocken, B.; Carmeliet, J. A review of wind-driven rain research in building science. J. Wind Eng. Ind. Aerodyn. 2004, 92, 1079-1130. [CrossRef]

15. Kvande, T.; Lisø, K.R.; Hygen, H.O. Klimadata for dimensjonering mot regnpåkjenning (Climate data for design to rain). In SINTEF Building Research Design Guide 451.031; SINTEF: Oslo, Norway, 2013.

16. Kvande, T.; Lisø, K.R. Climate adapted design of masonry structures. Build. Environ. 2009, 44, $2442-2450$. [CrossRef]

17. Groot, C.J.W.P.; Gunnweg, J.T.M. The influence of materials characteristics and workmanship on rain penetration in historic fired clay brick masonry. Heron 2010, 55, 141-153.

18. Goodwin, F.; West, H. A Review of the Literature on Brick/Mortar Bond. In Proceedings of the British Masonry Society, Load Bearing Brickwork (7); British Ceramic Society: Stoke-on-Trent, UK, 1982; pp. 23-37.

19. Bowler, G.K.; Jackson, P.J.; Monk, M.G. The Role of Mortar Workability (Cohesivity) in the Rain Penetration of Masonry. Int. Masonry Soc. 1996, 10, 25.

20. Baker, L. Some Factors Affecting the Bond Strength of Brickwork. In Proceedings of the Fifth International Brick Masonry Conference, Washington, DC, USA, 5-10 October 1979; pp. 84-89.

21. Costigan, A.; Pavia, S. Effect of mortar water content in the properties of masonry. In Proceedings of the 9 th International Masonry Conference, Guimarães, Portugal, 7-9 July 2014.

22. Hutcheon, N.B. Silicone Masonry Water Repellents. Natl. Res. Counc. Can. 1963. [CrossRef]

23. Colorless Coatings for Brick Masonry. In Technical Notes on Brick Construction; The Brick Industry Association: Reston, VA, USA, 2008; Available online: http:/ /www.gobrick.com/portals/25/docs/technical\%20notes / tn6a.pdf (accessed on 18 May 2017).

24. Kvande, T. Fuging og tynne overflatebehandlinger på teglfasader (Jointing and thin surface treatments on masonry veneers). In SINTEF Building Research Design Guide 542.801; SINTEF: Oslo, Norway, 2015; Available online: https:/ / www.byggforsk.no/dokument/485/fuging_og_tynne_overflatebehandlinger_ paa_teglfasader (accessed on 4 June 2017).

25. Types of Masonry Water Repellents. Available online: https://www.gsa.gov/portal/content/112042 (accessed on 18 May 2017).

26. Lubelli, B.; van Hees, R.P.J. Evaluation of the Effect of Nano-Coatings with Water Repellent Properties on the Absorption and Drying Behaviour of Brick. In 6th International Conference on Water Repellent Treatment of Building Materials; Aedificatio Publishers: Freiburg, Germany, 2011; pp. 125-136. ISBN 978-3-931681-99-9. Available online: http:/ / www.hydrophobe.org/pdf/rome/VI_12.pdf (accessed on 09 June 2017).

27. Wienerberger. Decleration of Performance, DoP-Number: 21115190-A1W2111; Wienerberger AB: Malmö, Sweden, 2016. 
28. Saint-Gobain Byggevarer as (2014) NEPD00130E Rev1, weber Murmørtel M5, dry mortar. Available online: https:/ / www.weber-norge.no/fileadmin/user_upload/EPD/NEPD00130E_Rev1_weber_murmoertel_ M5_GODKJENT.pdf (accessed on 31 May 2017).

29. Weber Saint Gobain (2016) Decleration of Performance, Nr. DoP-NO-M418972222, Version 2. Available online: https://www.weber-norge.no/uploads/tx_weberproductpage/dop-1_Weber_Murm_ rtel_M5.pdf (accessed on 31 May 2017).

30. NBI 29/1983 Mørtler. Tetthet mot slagregn (Mortars. Resistance to driving rain); Norges byggforskningsinstitutt: Oslo, Norway, 1983; pp. 75-76. ISBN 82-536-0184-0.

31. Einstadblad, H.; Westbye, A. Murverk av tegl-Sammenheng mellom utførelse og kvalitet (Clay brick masonry-Relations between workmanship and quality). Master Thesis, Norwegian University of Science and Technology, Trondheim, Norway, December 1999.

32. Kvande, T.; Lisø, K.R. Regendichter Putz für gemauerte Fassaden. Das Mauerw. 2003, 2, 59-65.

33. Ioannou, I.; Hoff, W.D. Water repellent influence on salt crystallisation in masonry. Proc. Inst. Civil Eng. Constr. Mater. 2008, 161, 17-23. [CrossRef]

(C) 2017 by the authors. Licensee MDPI, Basel, Switzerland. This article is an open access article distributed under the terms and conditions of the Creative Commons Attribution (CC BY) license (http:/ / creativecommons.org/licenses/by/4.0/). 